

\title{
BEBAN KELUARGA DALAM MERAWAT ANAK AUTIS
}

\author{
Ns. Yola Yolanda., M. Kep \\ Ns. Velga Yazia., M. Kep \\ Ns. Ulfa Suryani., M. Kep., Sp. Kep. J
}

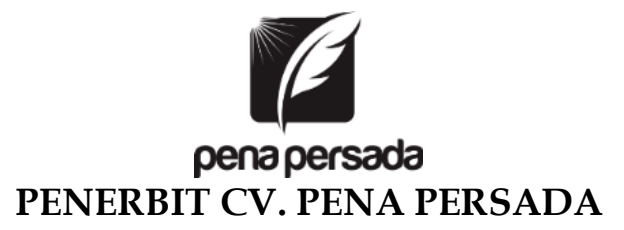




\section{BEBAN KELUARGA \\ DALAM MERAWAT ANAK AUTIS}

Penulis:

Ns. Yola Yolanda., M. Kep

Ns. Velga Yazia., M. Kep

Ns. Ulfa Suryani., M. Kep., Sp. Kep. J

ISBN : 978-623-315-056-9

Design Cover :

Retnani Nur Briliant

Layout :

Nisa Falahia

Penerbit CV. Pena Persada

Redaksi :

Jl. Gerilya No. 292 Purwokerto Selatan, Kab. Banyumas Jawa Tengah

Email : penerbit.penapersada@gmail.com

Website : penapersada.com Phone : (0281) 7771388

Anggota IKAPI

All right reserved

Cetakan pertama : 2020

Hak Cipta dilindungi oleh undang-undang. Dilarang memperbanyak karya tulis ini dalam bentuk apapun tanpa izin penerbit 


\section{KATA PENGANTAR}

Puji syukur penulis ucapkan kepada ALLAH SWT yang telah memberikan rahmat dan hidayah serta petunjuk sehingga penulis dapat menyelesaikan buku dengan judul "Beban Keluarga dalam Merawat Anak Autis". Buku ini disusun agar dapat membantu para pembaca dan mahasiswa dalam mempelajari beban keluarga saat merawat anak dengan Autis.

Salah satu kelebihan buku ini adalah buku ini membahas dengan detail tentang apa saja faktor yang menjadi beban keluarga dalam merawat anak Autis sehingga dapat menghasilkan informasi, salah satunya pentingnya dukungan sosial dan pendidikan pada keluarga dalam merawat anak Autis. Dengan adanya dukungan sosial yang baik dan pendidikan yang tinggi maka akan mengurangi beban keluarga dalam merawat anak Autis.

Pembahasan buku ini didasarkan pada hasil penelitian yang dilakukan oleh penulis. Agar hasil penelitian yang sudah dilakukan oleh penulis menjadi lebih bermanfaat maka perlu untuk ditulis ulang (dikonversikan) dalam bentuk buku. Dengan bentuk buku diharapkan bisa tersebar luas ke berbagai kalangan akademisi Perguruan Tinggi melalui beberapa perpustakaannya. Oleh karena itu, dalam membaca buku ini dengan benar dan untuk mendapatkan kesimpulan yang utuh maka disarankan untuk membacanya secara urut setiap BAB nya tanpa ada loncatan.

Dengan demikian harapan diterbitkan buku ini adalah bisa menjadi referensi dan bahan pembanding bagi para dosen, mahasiswa, maupun para peneliti. Serta bagi siapapun yang suka membaca dan menyukai perkembangan ilmu pengetahuan yang sedang aktif dalam berbagai bentuk 
penulisan, pengerjaan skripsi, pembuatan jurnal maupun artikel, dan kegiatan bermanfaat lainnya.

Sebagai penutup, apabila ada kesalahan itu hanya karena berasal dari penulis sendiri dan apabila ada kebenaran dan nilai manfaat dalam buku ini adalah sematamata karena bantuan berbagai pihak serta tentunya atas rahmat Allah SWT. Pada akhirnya penulis ucapkan terimakasih dan penghargaan kepada editor, petugas desain cover dan beserta tim penerbit Pena Persada lainnya yang telah bekerja keras dan berperan banyak untuk diterbitkannya buku ini secara layak. Sebuah keberuntungan bagi penulis telah mendapat bantuan orang-orang hebat seperti mereka sehingga buku ini bisa terwujud dan memadai untuk dibaca. Semoga Allah SWT membalas amal baik mereka dengan limpahan kesehatan, kesejahteraan dan kebahagian. Aamiin. 


\section{DAFTAR ISI}

KATA PENGANTAR ...................................................... ii

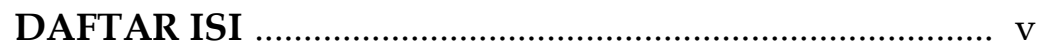

BAB I PENDAHULUAN ................................................... 1

BAB II AUTISME ......................................................... 11

A. Pengertian Autisme ............................................... 11

B. Klasifikasi Autisme ................................................ 12

C. Penyebab Autisme ................................................. 12

D. Perilaku Autisme .................................................... 13

E. Gangguan Anak Autisme ...................................... 14

F. Penanganan Autisme .......................................... 16

BAB III PERAN PERAWAT ….................................... 23

BAB IV INTERVENSI KEPERAWATAN JIWA, ANAK

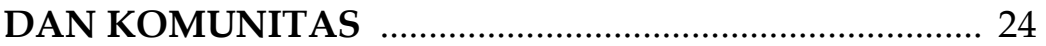

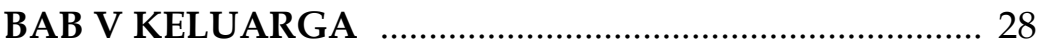

A. Defenisi Keluarga ................................................. 28

B. Struktur Keluarga ................................................. 28

C. Fungsi Keluarga ...................................................... 29

D. Peran Pelaku Rawat (keluarga) Anak Autis ........ 30

BAB VI FAKTOR YANG MEMPENGARUHI PELAKU

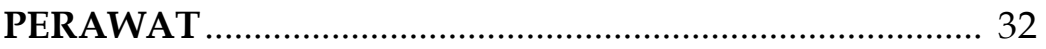

BAB VII HASIL RISET TERKAIT BEBAN KELUARGA DALAM MERAWAT ANAK AUTIS ................................ 35

A. Beban Keluarga ...................................................... 35

1. Defenisi Beban Keluarga .................................. 35

2. Dimensi Beban Keluarga .................................... 36

3. Faktor yang Berhubungan dengan Beban

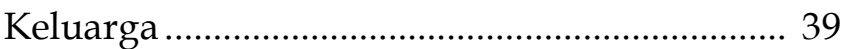

4. Kategori Beban Care Giver (Keluarga) ............... 44

5. Pengukuran Beban Keluarga ............................. 45 
B. Dukungan sosial ..................................................... 45

1. Pengertian Dukungan Sosial ............................ 45

2. Faktor yang Mempengaruhi Dukungan Sosial 46

3. Sumber Dukungan Sosial................................... 47

4. Pengukuran Dukungan Sosial............................. 47

C. Dukungan Sosial dengan Beban Keluarga............. 48

1. Dukungan Sosial ............................................... 50

2. Beban Keluarga ................................................. 51

3. Dukungan Sosial dan Beban Keluarga ............. 53

4. Karakteristik dengan Beban Keluarga .............. 57

a. Usia .............................................................. 57

b. Pendidikan .................................................... 58

c. Pekerjaan ........................................................ 60

d. Penghasilan .................................................... 61

e. Jumlah Anak .................................................. 62

BAB VIII FAKTOR DOMINAN MEMPENGARUHI

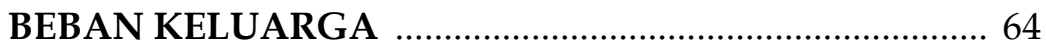

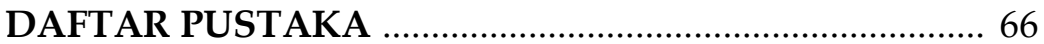




\section{BAB I \\ PENDAHULUAN}

Anak merupakan sebuah karunia yang besar bagi orang tuanya, keberadaannya diharapkan dan ditunggutunggu serta disambut dengan penuh bahagia. Semua orang tua mengharapkan memiliki anak sehat, membanggakan, dan sempurna, akan tetapi terkadang kenyataan yang terjadi tidak sesuai dengan keinginan. Sebagian orang tua mendapatkan anak yang diinginkannya dan sebagian lagi tidak. Beberapa diantaranya memiliki anak dengan kebutuhan khusus, seperti mengalami autisme (Hasdiah, 2013).

Autis merupakan salah satu kelompok dari gangguan pada anak yang ditandai munculnya gangguan dan keterlambatan dalam bidang kognitif, komunikasi, ketertarikan pada interaksi sosial, dan perilakunya. Autisme merupakan perilaku yang penderitanya hanya tertarik pada aktivitas mentalnya sendiri. Autis dapat terjadi di semua kalangan masyarakat (Veskarisyanti, 2008).

Jumlah anak yang terkena autis semakin meningkat pesat diberbagai belahan dunia. UNESCO (2011) melaporkan, tercatat 35 juta orang penyandang autisme diseluruh dunia. Ini berarti rata-rata 6 dari 1.000 orang di dunia mengidap autisme. Center for Disease Control (CDC) melaporkan di Amerika perbandingan autisme adalah 1:80. Di Asia yaitu di Hongkong prevalensi anak autis 1,68 per 1.000 untuk anak di bawah 15 tahun (Sirrait, 2013). Di Indonesia yang berpenduduk 200 juta lebih, diperkirakan jumlah anak autisme mencapai 150-200 ribu orang. Perbandingan antara laki-laki dan perempuan adalah 4:1, 
namun anak perempuan yang terkena akan menunjukkan gejala yang lebih berat (Huzaemah, 2010).

Anak autisme dapat mencapai pertumbuhan yang optimal jika didukung dengan penanganan yang baik ini membutuhkan keterbukaan dari orang tua untuk mengkomunikasikan kondisi anak mereka secara jujur pada dokter jiwa, dokter anak, psikolog, guru sekolah, termasuk saudara-saudara didalam keluarga besar (Triyosni, 2013).

Reaksi pertama orang tua ketika anaknya dikatakan bermasalah adalah tidak percaya, shock, sedih, kecewa, menolak. Hal ini tidak mudah bagi orang tua yang anaknya menyandang autisme untuk mengalami fase ini, sebelum akhirnya sampai pada tahap penerimaan (acceptance). Ada masa orang tua merenung dan tidak mengetahui tindakan tepat apa yang harus diperbuat. Hal ini menyebabkan banyak orang tua yang kemudian memilih tidak terbuka mengenai keadaan anaknya kepada teman, tetangga bahkan keluarga dekat sekalipun, kecuali pada dokter yang menangani anaknya tersebut (Safaria, 2005).

Hasil penelitian Halroyd dan Mc Arthur (1976) dalam Tobing (2012) menyatakan bahwa orang tua dengan anak autisme memiliki tingkat stres yang lebih tinggi dibandingkan dengan orang tua yang memiliki anak Down Syndrome. Selain itu, orang tua dengan anak autisme memiliki stres yang lebih besar dibandingkan orang tua dengan anak yang menderita kesulitan belajar. Stres tersebut dapat berpengaruh pada peran ibu terutama dalam merawat, mengasuh, dan mendidik anak. Hal ini akan mempengaruhi anak dan keluarga.

Schieve, et al (2007) menemukan bahwa kesulitan dalam menentukan perawatan kesehatan, intervensi dan terapi pada anak autis, beban finansial, pekerjaan dan waktu yang terkait jelas besar sekali untuk keluarga-keluarga 
Autisme Syndrome Disorder (ASD). Harvard, dan Ganz (2007) dalam Sastry (2014) mengungkapkan hal yang sama yaitu melalui penelitian tentang biaya perawatan seumur hidup untuk satu individu dengan autisme adalah lebih dari 3,2 juta dolar. Jika dikalikan dengan jumlah individu yang terkena, maka ini adalah biaya yang sangat besar untuk perawatan kesehatan pada anak autis. Hal ini akan menjadi sumber beban bagi keluarga merawat anak autis dan akan lebih terasa pada keluarga anak autis yang berpendapatan rendah sehingga memperluas dampak dari kemiskinan, .

Memiliki anak yang berkebutuhan khusus (autis) sangat mempengaruhi ibu, ayah dan semua anggota keluarga dengan rentang stres dan dinamika emosi yang sangat berviariasi (Hardman, 2012 dalam Hidayati 2011). Hal ini dibuktikan oleh penelitian Mugno (2007) mengkaji kehidupan keluarga yang memiliki anak autis secara detail yaitu sebanyak 299 orang tua diketahui keterlibatan orang tua dengan anak autis tetapi mengalami kondisi fisik yang lebih buruk karena stres pengasuhan anak karena yang menderita gangguan Autisme Syndrome Disorder(ASD), beban pengasuhan dan stres pengasuhan berkaitan dengan tingginya tingkat psikologi dan depresi.

Mulyadi (2013) menyatakan persepsi negatif serta evaluasi diri negatif sering dialami oleh orang tua yang memiliki anak autisme, diantaranya perasaan tidak mampu, bersalah dan malu. Pada akhirnya akan menyebabkan orang tua berada pada kondisi putus asa. Sikap putus asa justru membuat orang tua melakukan hal yang keliru dan fatal bagi anak dan diri orang tua sendiri. Hal ini jika tidak dilakukan penanganan lebih lanjut maka sikap panik mungkin dihadapi orang tua anak autis terutama ibu. Orang tua akan mengalami kesulitan dalam mendapatkan informasi yang benar mengenai gangguan autisme yang 
pada akhirnya menjadi keliru dan berakibat buruk untuk masa depan anaknya.

Orang tua yang memiliki anak penyandang autisme segala sesuatunya pasti tampak berbeda dari orang tua lainnya. Merupakan periode awal kehidupan anaknya yang merupakan masa-masa tersulit dan paling membebani. Pada periode ini sering kali orang tua berhadapan dengan begitu banyak permasalahan. Tidak saja berasal dari anaknya tetapi bercampur dengan masalah-masalah lainnya yang dapat membebani orang tua, termasuk permasalahan yang muncul dari reaksi masyarakat (Safaria, 2005).

Banyak masyarakat luas yang belum memahami tentang autisme. Penolakan terhadap anak-anak ini terlihat ketika mereka sulit diterima untuk bersekolah disekolahsekolah umum sebagaimana anak lainnya. Hal ini dapat menjadi beban bagi sebagian keluarga yang memiliki anak autis. Ada perasaan malu dan perasaan untuk menjauh dari kehidupan sosialnya (Marijani, 2013).

Kehidupan keluarga yang memiliki salah satu anak yang mengalami autisme merupakan suatu cobaan yang menjadi pekerjaan berat sehari-harinya. Tidak mudah bagi ibu untuk dapat hidup secara tenang dan damai ketika mengetahui anaknya mengalami salah satu gangguan perkembangan yang cukup berat seperti autisme (Safaria, 2005). Hal ini akan berdampak negatif pada fisik orang tua.

Beban yang berdampak negatif pada fisik meliputi kelelahan dan keluhan otot. Kelelahan biasanya ditandai dengan berkurangnya kemauan untuk bekerja disebabkan oleh intensitas dan lamanya kerja fisik, keadaan lingkungan, mental, status kesehatan dan status gizi (Tarwaka, Bakhri \& Sudiajeng, 2011). Hal ini membutuhkan dukungan sosial dari lingkungannya. 
Menurut penelitan Milyawati (2009) didapatkan hampir separoh ibu $(45,2 \%)$ memperoleh dukungan sosial yang kurang kuat dalam merawat anak autis di kota Surabaya. Beberapa hasil penelitian telah dilakukan untuk menggali pengalaman keluarga dalam merawat anak dengan kebutuhan khusus. Retzlaff (2007) melakukan penelitian pada keluarga yang memiliki anak dengan Rett Syndrome, dan menyatakan bahwa untuk dapat bertahan keluarga membutuhkan tingkat adaptasi yang tinggi dengan dukungan secara internal dan eksternal. Sementara Raper (2007) menyatakan bahwa tingkat adaptasi sebuah keluarga yang merawat anak dengan Down Syndorome (berkebutuhan khusus) dipengaruhi oleh tiga faktor, yaitu kebutuhan keluarga dalam pengasuhan, sumber pendukung yang tersedia dalam keluarga melalui komunikasi yang baik. Keluarga yang memiliki anak dengan autisme kebanyakan sangat membutuhkan adaptasi dalam sistem keluarga sehingga dapat memberikan dukungan yang optimal selama merawat anak dengan autisme.

Fitrasari (2009) melakukan penelitian pada keluarga yang memiliki anak dengan autisme dan menyatakan perasaan berduka yang dirasakan oleh keluarga terjadi melalui tahapan menyangkal, marah, tawar-menawar, depresi dan menerima serta berbagai penyebab berduka tersebut menyebabkan berbagai beban dalam keluarga sehingga memerlukan dukungan sosial dan finansial selama merawat anak dengan autis.

Anak kebutuhan khusus seperti autis memerlukan perlakuan yang wajar, bimbingan, pengarahan, belajar tentang pola-pola perilaku yang dapat diterima sehingga tidak menghambat perkembangan (Nam, dkk,2009). Perkembangan anak (termasuk didalamnya anak berkebutuhan khusus) dipengaruhi oleh lingkungan 
sekitarnya melalui sosialisasi. Anak disosialisasikan dan didukung oleh keluarganya, sekolah, dan masyarakat tempat ia berada (Hidayati, 2011).

Kehidupan anak juga sangat ditentukan keberadaannya bentuk dukungan dari keluarga. Hal ini dapat dilihat apabila dukungan keluarga anak kurang baik, maka anak mengalami hambatan pada dirinya yang dapat mengganggu psikologis anak (Alimul, 2009). Hasil penelitian lain yang dilakukan oleh Gusti (2014) menunjukkan bahwa keluarga yang merawat anak autis mendapat dukungan sosial keluarga baik sebanyak (57,9\%) sedangkan responden dengan dukungan sosial keluarga tidak baik sebanyak (42,1\%).

Tingkatan dukungan sosial antara satu orang dengan orang lain berbeda-beda. Hal tersebut disebabkan dari persepsi masing-masing dalam penerimaan dan merasakannya. Dukungan akan dirasakan apabila diperoleh dari orang-orang yang dipercayainya. Dengan begitu seseorang akan mengerti orang lain akan menghargai dan mencintai dirinya (Rustiani, 2009).

Keterbatasan anak juga berdampak pada sisi emosi orang tua karena harapan orang tua tidak terpenuhi. Hal tersebut diperkuat oleh Mangunsong (2011) bahwa reaksi umum yang terjadi pada orang tua adalah perasaan sedih, kecewa, adanya rasa bersalah, bahkan menolak dan marah. Idealnya ketika orang tua mengalami berbagai tekanan dan perasaan, mengharapkan lingkungan dapat membantu orang tua, salah satunya dengan memberikan dukungan agar orang tua mampu menjalankan peran sebagai orang tua anak autis. Namun pada kenyataannya, orang tua yang memiliki anak autis lebih sering dikritik orang lain terkait kondisi anaknya. Tidak sedikit reaksi masyarakat yang menimbulkan perasaan tidak nyaman, sehingga orang tua 
yang memiliki anak autis merasa bahwa dirinya diasingkan karena kondisi anaknya.

Orang tua juga tidak terlepas dari kondisi stres, depresi, cemas, dan tekanan lain yang dialami selama mengasuh anak, kondisi tersebut juga mempengaruhi kemampuan orang tua dalam mengasuh. Situasi tersebut dapat diatasi dengan adanya dukungan sosial (Mangunsong, 2011).

Yuwono (2012) menyatakan keluarga dianggap satu subyek yang sangat rentan dililit masalah dan sangat urgen untuk segera diberikan pertolongan agar keluarga tidak terjebak dalam masalah yang semakin rumit. Bila tidak segera diberikan pertolongan, perilaku keluarga saat menghadapi anak autistik akan mengarah pada jalur dan cara-cara yang salah sehingga anak autistik tidak mencapai perkembangan yang maksimal.

Salah satu faktor yang mempengaruhi keberhasilan keluarga yang memiliki anak autis adalah dukungan sosial. Dukungan sosial berperan penting dalam memelihara keadaan individu yang mengalami tekanan. Dukungan sosial tersebut melibatkan hubungan sosial yang berarti, sehingga dapat menimbulkan pengaruh positif yang dapat mengurangi gangguan psikologis sebagai pengaruh dari tekanan. Dukungan dari teman, anggota keluarga, dan lingkungan sosial yang merupakan salah satu bentuk dari dukungan emosional, akan sangat membantu seseorang dalam menghadapi masalah. Bentuk dukungan mereka berupa perhatian, empati, kepedulian dan kasih sayang. Jika ini terlaksana maka akan sangat membantu keluarga dalam menerima kenyataan sehubungan dengan kondisi anaknya (Sastry, 2012). 
Pada umumnya dukungan sosial dapat ditemukan pada hubungan antar pribadi yang ditandai oleh kedekatan dan sikap saling percaya. Dukungan sosial yang dibutuhkan tergantung pada dinamika yang sedang dirasakan yang dapat disesuaikan dengan pengalaman yang terjadi. Dukungan sosial yang diperoleh dari kelompok dapat menimbulkan rasa aman dalam melakukan partisipasi aktif, eksplorasi, dan eksperimentasi dalam kehidupan yang akhirnya meningkatkan rasa percaya diri, keterampilan keterampilan dan strategi menghadapi masalah (Smet, 1994). Dukungan sosial akan memberikan dampak positif, agar orang tua yang memiliki anak autis, tetap berusaha mengasuh dan mengembangkan kemampuan anak semata wayangnya yang membutuhkan penanganan khusus. Orang tua yang membesarkan anaknya dengan sedikit dukungan dari lingkungan akan sering merasa bahwa mereka diasingkan mengenai kondisi anaknya. Seolah-olah orang tua dianggap tidak mampu untuk merawat anaknya. Hal ini akan meningkatkan stres keluarga.

Penelitian Gupta (2005) mendapatkan gambaran bahwa dukungan sosial dapat mengurangi tingkat stres pada orang tua dari anak autis berisiko tinggi untuk depresi, merasa diisolasi dari lingkungan sosialnya dan perselisihan perkawinan. Penelitian Siklos \& Kerns, (2006) mendapatkan hasil bahwa orang tua dari anak-anak dengan autis yang menerima dukungan sosial dari lingkungan yang berdampak dapat mengurangi stress. Sehingga mereka mampu mengatasi permasalahan dan berusaha untuk meluangkan waktu untuk hadir dalam suatu pertemuan kelompok dukungan masyarakat.

Penelitian Meral \& Cavkaytar (2012) mendapatkan hasil bahwa dengan adanya dukungan dari orang terdekat misalnya dari keluarga, kerabat dekat, tetangga maupun 
lingkungan lain yang mampu membicarakan masalah pribadi terkait anaknya, dari penelitian tersebut dapat ditunjukkan bahwa terjadi peningkatan persepsi akan dukungan yang diberikan lingkungan terhadap orang tua anak autis. Sehingga dengan dukungan tersebut, orang tua mampu merasa terbantu dan bekerjasama dalam mendukung peran satu sama lain dengan pasangan.

Berbeda dengan 3 caregiver lainnya merasakan dukungan dari keluarga terutama suami karena suami selalu memberi dukungan baik finansial maupun tempat berbagi suka dan duka, ada teman tempat berbagi dalam berbagi suka dan duka, dan lingkungan sekitar yang selalu perhatian dan peduli dengan caregiver. Walaupun demikian keluarga tetap saja membutuhkan dukungan dari tenaga kesehatan.

Bantuan tenaga kesehatan profesional yang salah satunya adalah perawat, khususnya perawat jiwa. Sejalan dengan falsafah keperawatan jiwa yaitu pelayanan keperawatan pofesional didasarkan pada ilmu keperawatan jiwa pada manusia sepanjang siklus kehidupan dengan respon bio-psiko-sosial yang maladaptif yang disebabkan oleh gangguan bio-psiko-sosial, dengan menggunakan diri sendiri dan terapi keperawatan jiwa (komunikasi terapeutik, dan terapi modalitas keperawatan kesehatan jiwa). Melalui pendekatan proses keperawatan untuk meningkatkan, mencegah, mempertahankan dan memulihkan masalah kesehatan jiwa klien (individu, keluarga, kelompok dan komunitas), maka perawat CMHN (Community Mental Health Nursing) sangat berperan dalam pengembangan Intervensi keperawatan jiwa yang difokuskan pencegahan primer, sekunder dan tersier serta melakukan pendidikan kesehatan jiwa bagi keluarga yang merawat anak autis, 
sumber dukungan yang diinginkan keluarga untuk mengurangi beban dalam merawat anak autis 


\section{BAB II \\ AUTISME}

\section{A. Pengertian Autisme}

Autisme mengacu pada problem dengan interaksi sosial, komunikasi, dan bermain imajinatif, yang mulai muncul sejak anak berusia dibawah 3 tahun. Mereka mempunyai keterbatasan pada level aktivitas dan interest. Hampir 75\% dari anak autis mengalami beberapa derajat Retardasi mental. Autisme biasanya muncul sejak tiga tahun pertama kehidupan seorang anak (Priyatna, 2010).

Autis merupakan salah satu kelompok dari gangguan pada anak yang ditandai munculnya gangguan dan keterlambatan dalam bidang kognitif, komunikasi, ketertarikan dan interaksi sosial, dan perilakunya. Autisme merupakan kelainan perilaku yang penderitanya hanya tertarik pada aktivitas mentalnya sendiri. Autis dapat terjadi di semua kalangan masyarakat (Veskarisyanti, 2008).

Autis adalah suatu keadaan dimana seseorang anak berbuat semaunya sendiri baik cara berpikir maupun berperilaku. Keadaan ini mulai terjadi sejak usia masih muda, biasanya sekitar usia 2-3 tahun autisme bisa mengenai siapa saja, baik yang sosio-ekonomi mapan maupun kurang, anak atau dewasa dan semua etnis (Yatim, 2010). 


\section{B. Klasifikasi Autisme}

Menurut Verkarisyanti (2008), ada beberapa klasifikasi austisme, diantaranya :

1. Aloof

Anak dengan autisme dari tipe ini senantiasa berusaha menarik diri dari kontak sosial, dan cenderung untuk menyendiri di pojok.

2. Passive

Anak dengan autisme tipe ini tidak berusaha mengadakan kontak sosial melainkan hanya menerima saja.

3. Active but odd

Sedangkan pada tipe ini, anak melakukan pendekatan namun hanyabersifat reperitif dan aneh.

\section{Penyebab Autisme}

Menurut Huzaemah (2010), autis disebabkan multi faktor, yaitu :

1. Kerusakan jaringan otak

Patricia Rodier, ahli embrio dari Amerika menyatakan bahwa korelasi antara autis dan cacat lahir yang disebabkan oleh Thalidomide menyimpulkan bahwa kerusakan jaringan otak dapat terjadi paling awal 20 hari pada saat pembentukan janin. Peneliti lainnya Minshe menemukan bahwa pada anak yang terkena autis, bagian otak yang mengendalikan pusat memori dan emosi menjadi lebih kecil dari pada anak normal.

Penelitian ini menyimpulkan bahwa gangguan perkembangan otak telah terjadi pada semester ketiga saat kehamilan, atau pada saat kelahiran bayi. Karin delson, ahli neurology Amerika mengadakan penyelidikan terhadap protein otak dari contoh darah 
bayi yang baru lahir. Empat sampel protein dari bayi yang normal mempunyai kadar protein tinggi, yang kemudian ditemukan bahwa bayi dengan kadar protein tinggi ini berkembang menjadi autis dan keterbelakangan mental (Huzaemah, 2010).

2. Terlalu banyak vaksin Hepatitis B

Ada pendapat yang mengatakan bahwa terlalu banyak vaksin Hepatitis B bisa mengakibatkan anak mengidap penyakit autisme. Hal ini dikarenakan vaksin ini mengandung zat pengawet Thimerosal.

3. Kombinasi makanan atau lingkungan yang salah

Kombinasi makanan yang salah atau lingkungan yang terkontaminasi zat-zat beracun yang mengakibatkan kerusakan pada usus besar, yang mengakibatkan masalah dalam tingkah laku dan fisik termasuk autis.

\section{Perilaku Austistik}

Autisme merupakan sindroma yang sangat kompleks. Ditandai dengan ciri-ciri kurangnya kemampuan interaksi sosial dan emosional, sulit dalamkomunikasi timbal balik, minat terbatas, dan perilaku tidak disertai gerakan berulang tanpa tujuan (stereo-tipic).

Menurut Safaria (2005), menyebutkan 2 jenis perilaku autisme, yaitu:

1. Perilaku berlebihan (excessive) :

a. Perilaku melukai diri sendiri (self-abuse), seperti memukul, menggigit, dan mencakar diri sendiri.

b. Agresif, seperti perilaku menendang, memukul, menggigit, dan mencubit.

c. Tantrum,seperti perilaku menjerit, menangis, dan melompat-lompat. 